\title{
On the Double Nature of the Cycadean Integument.
}

\author{
BY \\ MARIE C. STOPES.
}

T NTEREST in the morphology of the ovules of living Cycads has been 1 much stimulated by the recent appearance of several papers dealing with the structure of Cycad-like seeds of Carboniferous age. The structures found in these fossils are not only of great interest in themselves, but also seem to throw light on some of the difficult points in the morphology of recent seeds, and it became clear that a detailed examination of the living forms might be undertaken with advantage. This I attempted to do, publishing the chief details with a short outline of the results in August, $1904^{1}$.

In support of my views on the nature of the Cycad integument, through the kindness of Prof. Oliver, I was enabled to use certain facts discovered by him in the fossil Lagenostoma; but my paper was written prior to the publication of the full monograph on Lagenostoma which appeared almost simultaneously with it ${ }^{2}$. A large paper by M. Matte ${ }^{3}$, in which one of the sections treats of the Cycad ovule, appeared almost at the same time, so that the author had seen neither the full work on Lagenostoma nor mine on the Cycads.

In their monograph on Lagenostoma the authors state (p. 234): 'A comparison of the seeds of Cycads with Lagenostoma is inevitable,' and further: 'In any case, the detailed structure of Cycadean seeds is a subject fully deserving of further attention and elucidation.'

As it happened that the three papers dealing with the Cycads and Lagenostoma appeared simultaneously this comparison has not yet been fully made. I will not attempt to do this now in detail, but there are one or two points about which I should like to add something to my published views.

Work on the anatomy and morphology of living Cycads revealed that their integumentary structure is more complex than was generally

1 Stopes, Beitıäge zur Kenntnis d. Fortpflanzungsorgane d. Cycadeen. Flora, Bd. 4, I904.

2 Oliver and Scott, 'On the structure of the palaeozoic seed Lagenostoma Lomaxi.' Phil. Trans. B., vol. cxcvii, 1904 .

3 'L'appareil libéro-ligneux d. Cycadacées.' Caen, 1904.

[Annals of Botany, Vol. XIX. No. LXXVI. October, 1905.] 
supposed $^{1}$, and for the sake of the present argument I will summarize the most important of these points.

The first thing to be established was the fact that the inner of the two series of vascular bundles penetrating the ovule and generally termed the 'nucellar' series was truly integumentary. Facts supporting this were found in a large number of species, the most important case being that of Cycas circinalis, where not only are these bundles definitely seen to run in the inner layers of the integument, which is clearly marked off from the nucellus, but they are found to be continued in the integument almost to the micropyle, passing beyond the level at which the nucellus becomes free from the integument. The nucellus itself was found to be entirely devoid of vascular tissue throughout.

In addition, it was found that within the stone are tissues of considerable importance, in which this inner series of bundles runs and which form a very definite inner layer to the integument, although this has been frequently overlooked owing to its liability to get crushed in the ripening seed.

The integumentary nature of the inner vascular strands being established, the course of the bundles of the two systems was examined in detail, the result being the recognition that through all the various specific and generic variations which tend to mask it more or less completely there runs a central plan for their arrangement. This may be shortly described as consisting of a strand which gives off a series of bundles to the outer flesh of the ovule-coat, and continues its way, dividing up to form the inner series which may be further supplemented from the outer series. This is seen best in Cycas, Dioon, and Zamia, though in many cases the bundles appear to come off at the same level. In anatomical structure the main supply bundle is usually either completely concentric or has a strong tendency in that direction; the bundles given off to the outer flesh are collateral and orientated with the phloem outwards and with a considerable development of centripetal xylem; the strand continuing to supply the inner system has a strong concentric tendency, as have also those auxiliary ones derived from the outer series; the actual bundles of the inner series are orientated in the same sense as the outer, but with little, if any, centripetal xylem and seldom with definite spiral protoxylem.

These facts suggested a comparison with Lagenostoma and its cupule, in which the details of vascular arrangement and structure are strikingly parallel.

Now that all the facts for Lagenostoma are before one, this comparison appears to be justified in the main. One is not 'arguing in a circle,' but rather placing the facts from either side so as to act as props which enable 
the theory to stand. To explain Lagenostoma without the Cycads or the Cycads without Lagenostoma becomes a doubly difficult task.

Matte's work on the recent Cycads appears to have led him to a similar conclusion, though his work is from rather a different point of view. In his description of the vascular system of the ovule he substitutes the adjective 'périnucellaire' for the 'nucellaire' of previous descriptions. He does this, however, not so much as the result of independent observations of the facts of the case, but as he says (p. I68), in the presence of the work of Oliver and Scott and others, 'il est bon d'agir avec la plus grande circonspection en ce qui concerne l'attribution exclusive de cette couronne au nucelle de l'ovule.' He adds, 'En effet, en raison des rapports que les faisceaux de la couronne tégumentaire contractent avec ceux du reste de l'écaille, en raison aussi des rapports que les faisceaux de la couronne périnucellaire contractent avec ceux de la couronne dite tégumentaire, je suis amené à penser que ces derniers correspondent au système nervulaire d'une foliole ou de pinnules d'une penne relevées et concrescentes en cupule et que le système périnucellaire représente une chose ajoutée accidentellement insérée sur elles,' suggesting further that the 'systeme tégumentaire' is the equivalent of the cupular bundles of Lagenostoma, and the 'système nucellaire' that of the vessels penetrating the integument. This unites the work from the side of recent Cycads on this point.

The views of Oliver and Scott are expressed in their monograph, where they state (loc. cit., p. 234): 'The canopy of a Lagenostoma may well have undergone simplification into the hard integument of a Cycadean seed, and, in that case, the vascular strands, which run in or near the plane of union of nucellus and integument in the latter, should correspond with the integumental bundles of Lagenostoma, even though they no longer pass into the free part of the integument.' Now that it is known that in the living Cycads the inner series of bundles runs definitely not 'in or near the plane of union of nucellus and integument' but actually in an inner layer of the integument, and that in addition it is not universally true that they ' no longer pass into the free part of the integument,' but that in certain species they do pass beyond the free part of the nucellus and run in the free integument almost to the micropyle, this rather tentative suggestion may be considered to have accumulated force.

The authors continue: 'Whether the fleshy sarcotesta of Cycas, with its vascular strands, corresponds to a completely adnate cupule, may perhaps, be left an open question.' The strengthening of the previous position adds support also to this, and further the marked detailed likeness between the structure and arrangement of the bundles of Cycas and Lagenostoma adds weight to the view that they do correspond morphologically if not 'completely.' 
One or two further details may be worthy of mention. In the above quotation it is stated that 'The canopy of a Lagcnostoma may well have undergone simplification into the hard integument of a Cycadean seed.' I had previously looked upon the stone layers as belonging morphologically to the outer flesh, and did so on the ground that it was generally much more difficult to draw a boundary line between these two layers than between the stone and the inner flesh, which are always distinct; that the bundles of the outer flesh are in some cases partly embedded in the stone layers while the bundles of the inner flesh are distinct from it; and also that in the young ovule differentiation and sclerification of the stone cells start in the layers on the inner side and extend in an outward direction. In support of the other view, however, are the facts that the canopy tissue is hard, and that in Lagenostoma ovoides there are definite thickened cells in the outer zone of the integument.

It is very clearly marked in many Cycads that the stone has at least two layers, an inner one of mainly vertically running stone cells as in the integument of $L$. ovoides, and an outer one of mainly horizontally running stone cells. It may be that it is in the junction between these two layers of cells that we get the actual plane of fusion between the two integuments; the connexion between the outer stone layers and outer flesh in my eyes is too strong to allow of their morphological separation.

It is true that I have found in Encephalartos Barteri and other cases, in the stone freed from the flesh, a strong superficial likeness to the 'canopy' of Lagenostoma. This appearance, however, is correlated with the bending away from the stone of the bundles of the outer flesh as they go towards the micropyle, and although superficially it is strongly reminiscent of the canopy, yet as it is connected with the outer and not the inner series of bundles it can hardly be homologous with the canopy which belongs to the inner integument. Further, the well-marked ridges in the ripe stone, seen so clearly in Macrozamia spiralis, Encephalartos Altensteinii, \&c., are also the result of the close proximity of the bundles of the outer flesh to the stone, and these ridges always correspond exactly to the bundles, the number thus varying according to the number of the bundles, so that there are but two in Cycas, twelve in Macrozamia and so on. They do not thus correspond to the joined edges of leaflets as some exponents of the foliar theory of the ovule suggest, but may rather represent the vascular midrib of the lobes of the 'cupule'-like covering. In this way they may perhaps indicate the number of lobes in this covering, except in a case where definite reduction has taken place, as in Cycas, where the only remnant of the original radio-symmetry and many-bundled condition of the outer flesh is found just below the base of the seed.

These various considerations, combined with those before stated relative to the development, lead me to consider that at least the outer 


\section{Stopes.- On the Double Nature of the Cycadean Integument. $\quad 565$}

stone layers and outer flesh are one morphologically, and hence to look for the plane of fusion of the two integuments either between the inner and outer stone layers, or probably as I had originally suggested between the stone and the inner flesh.

The idea that an outer integument might arise as an independent outgrowth round the ovule in Cycads was suggested by Goebel ${ }^{1}$ some time ago, who stated that the 'Wucherungen' of Ceratozamia might represent the beginning of a second integument. If the Cycads, however, have already two integuments these 'Wucherungen' may represent a third. I have recently examined fresh material of Stangeria schizodon, in which there are upgrowths of the sporophyll which are developed to such an extent that in some cases they unite to completely enclose and cover over the growing ovule, even after it has attained a considerable size. 'Wucherungen' which completely enclose the ovule in this fashion can hardly be termed other than ovular coverings, and it seems to suggest the possibility of a third integument arising on much the same lines as I suppose the second to have done.

Although Oliver and Scott do not definitely state that they consider the cupule of Lagenostoma to be the equivalent of the outer flesh of Cycads, yet they suggest (p. 232 loc. cit.) that: "The outer (i. e. the cupular covering) is probably of later origin, and would appear to have afforded protection to the seed only when the latter was quite young. It is quite possible that the two enclosures have originated very similarly, i.e. as peltate-lobed structures, and that the present integument was once a comparatively unspecialized cupule-like indusium.'

If one can consider the inner integument as having once been a 'comparatively unspecialized cupule-like indusium,' I can see no reason why one cannot suppose the second 'cupule-like' structure to adhere and form the outer integument, nor why the series might not be continued and a third added in the same way. There appears to me to be no fundamental necessity to limit the integuments to two as Celakovsky has done.

The outgrowth I observed in Stangeria is entirely free from the outer integument of the ovule; it is undifferentiated in character, and its tissues are those of the sporophyll. It is obviously not split off from the outer integument, but is the free upgrowth round the already doubly integumented ovule, and it seems to me to illustrate markedly the case in point.

I have assumed throughout a sporangial theory of the ovule, an assumption that seems well justified in the light of recent work on fossils and living plants; the question under discussion is therefore only that of the nature of the integuments, and in particular the recognition of the double nature of the normal Cycadean integument.

\footnotetext{
1 Organographie der Pflanzen, I898, p. 786.
} 
On bringing together recent work on this subject as I have attempted to do, it appears to me that it unites in supporting the conclusion that in a Lagenostoma with its cupule we see the morphological equivalent of a Cycadean ovule with its complicated integument representing the inner and outer fused. A consideration of the envelopes of the two seeds together thus throws light upon each, and upon the origin of integumentary structures in general.

March I0, 1905 . 


\section{$2 \mathrm{BHL}$ Biodiversity Heritage Library}

Stopes, Marie Carmichael. 1905. "On the double nature of the cycadean integument." Annals of botany 19, 561-566.

https://doi.org/10.1093/oxfordjournals.aob.a089028.

View This Item Online: https://www.biodiversitylibrary.org/item/233541

DOI: https://doi.org/10.1093/oxfordjournals.aob.a089028

Permalink: https://www.biodiversitylibrary.org/partpdf/318816

\section{Holding Institution}

Smithsonian Libraries

\section{Sponsored by}

Biodiversity Heritage Library

\section{Copyright \& Reuse}

Copyright Status: Not in copyright. The BHL knows of no copyright restrictions on this item.

This document was created from content at the Biodiversity Heritage Library, the world's largest open access digital library for biodiversity literature and archives. Visit BHL at https://www.biodiversitylibrary.org. 